\title{
Implementation of Joint Regulation Policies of the Minister of Religion and Minister of Home Affairs Number 9 and 8 of 2006 through Empowerment of Religious Harmony Forums in Manado City
}

\author{
Muhamad Taher Tanggung ${ }^{1}$, Sri Suwitri ${ }^{2}$, Endang Larasati ${ }^{3}$, Rukmina Gonibala ${ }^{4}$ \\ ${ }_{1,2,3,4}$ Faculty of Social and Political Science, University of Diponegoro, Indonesia \\ Email:muhtanggung@gmail.com
}

\begin{abstract}
This study aims to determine how the Manado City Religious Harmony Forum from now on known as FKUB empowers the roles stipulated in Joint Regulations Number 9 and Number 8 of 2006 by the Minister of Religion and the Minister of Home Affairs. A qualitative approach was applied to this study using the literature review method. At the same time, perform data analysis in qualitative descriptions. This is because the policy's success depends very much on the role of the government, namely the government gives the authority to FKUB managers to act as a management team to deliver information on policies formulated by the central government to cities/regions. This structured accountability system is based on the bureaucracy's compliance with the upper-level bureaucracy or the designated level of bureaucracy. Is there a smooth routine procedure and whether there are problems and the expected implementation and implementation of all existing plans and plan targets-impact (benefit). Therefore, the policy implementation process's measurement is carried out to transfer information or news from a higher organization to a lower one.
\end{abstract}

Keywords: Policy Implementation, Empowerment, FKUB.

\section{A. INTRODUCTION}

The implementation of Joint Regulations 9 and 8 of 2006 between the Minister of Religion and the Minister of Home Affairs covers three main activities, namely; (1) Maintaining tolerance between religious communities; (2) activate FKUB; (3) adding places of worship. In this case, the local government starts from the governor to the village head.

The empowerment of FKUB brings a new direction in managing interreligious relations. The Religious Harmony Forum is a unique role that the state and social departments play in realizing a harmonious society between religions. In a pluralistic society, the management of various religious activities must pay attention to the principles of pluralism, tolerance, and mutual respect. The government, together with FKUB members, consists of multiple components of different religious groups. Harmonious life between religious communities is the concern and work plan of all parties. The government allocates a budget through the APBN and APBD to strengthen the Forum for Religious Harmony (FKUB). 
The government's policy to create religious harmony and regulate relations between religious communities and freedom to embrace religion and belief is stated in the 1945 Constitution, article $28 \mathrm{E}$, and article 9, paragraph 2. In exercising these rights and freedoms, everyone is obliged to comply with the restrictions set by law as recognition, guarantee, and respect for the rights and freedoms of others (Article $28 \mathrm{~J}$ paragraph (1) and (2). The government has followed up on the constitutional mandate by issuing several laws and policies in the field of religion, particularly related to harmony between people. The government and the community continue to strive to create and maintain religious harmony with their respective local wisdom (Yusuf, 2010)

As a democratic country, Indonesia continues to play a role in maintaining the country's harmony and integrity. Indonesia is undergoing rapid changes in various fields, such as the social, cultural, economic, political, and religious consequences of global developments and influences. On the one hand, if these changes are in line with the cultural and religious values that exist in society, these changes will positively impact the Indonesian nation in the future. Conversely, if these changes are not in line with cultural and religious values, it will be counterproductive (Mustafa, 2015).

Religious harmony is a precious asset for the survival of all Indonesians. Religious harmony is a dynamic thing that can change according to the behavior of its supporters. Therefore, religious leaders and community leaders' behavior plays an essential role in maintaining a conducive climate. This is where the importance of relations between religious communities plus, namely, a communicative relationship that is not limited to religious figures but also involves community leaders and bureaucratic government officials (Ali, 2011).

Arifuddin (2010), explains Indonesia is a country whose society is full of tolerance, so it tends to ignore the reality that religion contains a "disease," namely the potential for conflict. Various attempts have been made by the government to create harmony in diverse lives. In general, these efforts can be divided into constitutional and political efforts. This can be seen from Article 29 of the Constitution's affirmation to maintain people's diversity and harmony. Also, the 1998 MPR Session suggested that one of the reform efforts in religious life was to increase harmony between religious believers and build and authorize interfaith networks. Besides, various discussions took place internally and between religious believers and the government. Likewise, multiple workshops, briefings, dialogues, and community cooperation were also held.

Another step taken by the government is by issuing government regulations to encourage religious harmony. Through honesty and a genuine understanding of the existence of common ground (kalimah sawa') at a deep religious level, we can build genuine diversity and then make a harmonious life. Sincerity in understanding and completing a diverse life in a country is fundamental to maintain a harmonious and peaceful life. Hard work and various efforts have succeeded in creating a harmonious life, but unwillingness or compulsiveness among certain religious 
groups sometimes disturbs this harmonious life. History shows that cheating in completing different lives is often a stumbling block to maintaining social life harmony (Anang, n.d.).

Law Number 23 of 2014 concerning Regional Government, on general government affairs in article 25 letters (b) and (c), fostering national unity and integrity, as well as fostering harmony between ethnic groups, religious communities, races, and other groups to achieve stability and security local, regional, national. The Duties, Authorities, Obligations, and Rights of Regional Heads and Deputy Regional Heads are visible on local governments' responsibilities regarding religious harmony. In Article 65, paragraph 1 letter of Law Number 23 of 2014, "maintaining public order and order." This sentence implicitly emphasizes the obligations and responsibilities of regional heads and deputy regional heads in maintaining harmony in Indonesian society, which consists of religious people, or in other words, being responsible for maintaining "religious harmony" in their regions.

In the context of current regulations, the Regional Government's authority or obligation to maintain religious harmony is increasingly apparent with the issuance of PBM No. 9 and 8 of 2006. PBM, which in full is the Joint Regulation of the Minister of Religion and the Minister of Home Affairs Number 9 and 8 of 2006, containing the Guidelines for the Implementation of the Duties of Regional Heads / Deputy Regional Heads in Maintaining Religious Harmony, Empowering the Forum for Religious Harmony (FKUB), and the construction of houses of worship.

The Regional Government in implementing the joint regulation policy of the Minister of Religion and the Minister of Home Affairs Number 9 and 8 of 2006, which results from a joint agreement between the leaders of the religious councils and religious leaders. In the drafting of the Joint Ministerial Regulation, the government only played a role in facilitating and providing a regulatory legal umbrella to be applied in religious life in the Republic of Indonesia's territory.

The Joint Regulations Number 9 and Number 8 of 2006 by the Minister of Religion and the Minister of Home Affairs have a significant meaning and are a milestone in the Indonesian government's joint efforts to build and maintain religious harmony under the joint efforts of the government and religious groups.

Empowerment of religious harmony forums, there are at least 5 qualities of religious harmony that need to be developed, namely: the value of religiosity, harmony, dynamism, creativity, and productivity. First, the quality of religious life harmony must represent the religious attitude of the people. Second, it must reflect a harmonious pattern of interaction between fellow religious communities. Third, the development of dynamic values represented by an interactive atmosphere. Fourth, it must be oriented towards developing a creative atmosphere in various life sectors for meaningful mutual progress - fifth, creating people's productivity value and practical social values to alleviate poverty and ignorance.

In FKUB, the management of relations between religious communities is a concrete manifestation of the state's unique role and the social component in realizing religious harmony and paying attention to the principles of pluralism, 
tolerance, and mutual respect to manage various religious activities in a pluralistic society. The government and FKUB consist of multiple elements from different religious groups. Religious harmony is a principle that guides the attention and work of all parties. The government allocates a budget through APBN and APBD to strengthen the role of FKUB. Various religious organizations carry out different socialization, mediation, mentoring, and supervision through FKUB and independently to achieve religious harmony.

The Forum for Religious Harmony (FKUB) throughout Indonesia was inspired and continued with a dialogue forum for various religious beliefs. This forum existed before FKUB was born in 2006. The forum is PBM-based and used by people in multiple regions. Named after him, he aims to build religious harmony. Concerning the essence of the regulation in Article 1 Paragraph 6 "PBM 2006", FKUB is a "forum consisting of the community, facilitated by the government in the building's framework, maintaining and empowering religious communities to create harmony and prosperity." Building linkages in reservoir areas at the provincial and district/city levels.

Following Article 9 PBM 2006, as a forum officially legalized by the government, FKUB in each province, district (city) has the obligation and authority to dialogue with religious and community leaders, adjusting to religious mass's wishes and desires organizations. The community's wishes convey the wishes of mass organizations and the community in the form of suggestions, become material for governor/regent/mayor policies, and socialize laws and regulations and policies in the religious sector related to religious harmony and community empowerment. Apart from these responsibilities and authorities, municipal / regency FKUBs are specifically authorized to provide written advice on church construction requests.

The establishment of Houses of Worship in PBM Number 9 and 8 of 2006 is discussed in 3 Chapters and 10 articles, namely Chapter IV (Establishment of Houses of Worship) starting from article 13 to article 17, Chapter V (Temporary Permit for Building Utilization) from article 18 to article 20, and Chapter VI (Dispute Resolution) article 21 and 22. Article 13 states (1) The establishment of houses of worship is based on real and serious needs based on the population's composition for the community's services concerned in the village area. (2) As referred to in paragraph 1, the establishment of houses of worship shall be carried out while maintaining religious harmony, not disturbing public order and order, and complying with statutory regulations. (3) Suppose the real need for religious communities' services, as referred to in paragraph 1, is not fulfilled. In that case, the total population composition considerations shall be used for the district's boundaries or regency/city or province.

Regarding the requirements for the construction of houses of worship regulated in Article 14, namely; The construction of a place of prayer must fulfill the building's administrative and technical requirements. (paragraph 1). The requirements are to have a user marked with a user's ID card approved by local officials, local community support for at least 60 people authorized by the village 
head, a written recommendation from the head of the district/city religious department, and a written recommendation from the district/city FKUB. If the support requirements for at least 60 residents are not fulfilled, then PBM obliges the local government to facilitate the availability of locations to construct houses of worship (article 14 paragraph 3).

Regarding the temporary use of the building as a temporary house of worship regulated in Article 18 paragraph (3) with conditions; written permission from the building owner, written recommendation from the village head, written reporting to the district/city FKUB, and written reports to the head of the district/city head of the religious affairs ministry. As stipulated in Article 19 paragraph (2), the certificate for the granting of a temporary permit shall be issued for a maximum of two years.

Manado City is located in North Sulawesi Province and has approximately 373,494 people (Total population of Manado City in BPS Manado in 2015). Administratively, Manado City is the capital of North Sulawesi Province and borders the Main Regencies of Minahasa and Minahasa Utara to the north. Manado City is the heart of life in North Sulawesi Province and plays a vital role in the province's development and development. Almost all activities of the people of North Sulawesi are concentrated in Manado City.

As happened in city centers, Manado City is not only a center for urban production activities but also a place for religious, social, cultural, administrative, and commercial activities because the city center is very profitable economically and can help. The economic structure provides an enormous contribution. Seeing that Manado City has many races and religions, even though it is so diverse, Manado's people value tolerance, harmony, openness, and a vibrant attitude to life so that Manado City has a relatively conducive social environment. It is known as a relatively safe city in Indonesia.

Table 1 Total Population of Manado City

\begin{tabular}{|c|c|c|c|c|}
\hline \multirow[b]{2}{*}{ No } & \multirow[b]{2}{*}{ Sub-District } & \multicolumn{2}{|c|}{ Amount } & \multirow{2}{*}{ Percentage } \\
\hline & & Men & Women & \\
\hline 1. & Bunaken & 13,255 & 13,969 & 27,224 \\
\hline 2. & Tuminting & 30,530 & 31,200 & 61,730 \\
\hline 3. & Singkil & 30,101 & 30,554 & 60,665 \\
\hline 4. & Wenang & 19,659 & 19,827 & 39,486 \\
\hline 5. & Tikala & 17,491 & 18,025 & 35,516 \\
\hline 6. & Sario & 13,672 & 13,830 & 27,502 \\
\hline 7. & Wanea & 36,327 & 36,889 & 73,216 \\
\hline 8. & Mapanget & 32,554 & 33,303 & 65,857 \\
\hline 9. & Malalayang & 37,172 & 37,920 & 75,092 \\
\hline 10. & Bunaken Islands & 3,813 & 3,963 & 7,776 \\
\hline 11. & Paal Dua & 26,168 & 26,785 & 52,953 \\
\hline & Total & 260,742 & 266,265 & 527,007 \\
\hline
\end{tabular}

Source: Manado City Ministry of Religion Data for 2019 
The majority of the population in Manado is Protestant Christian, 289,530 people. Simultaneously, Islam is 128,483 in second place of the total population and Catholic Christians around 36,816 people, around Buddhists, 2,244 Hindus, 692 Confucians, and 499 people (Data from the 2015 North Sulawesi Ministry of Religion). They are experiencing growth every year. Many newcomers visit or settle down as the city of Manado develops.

Data on facilities for places of worship for Christians and Muslims and other religious groups increases every year along with the city's development, especially the expansion of settlements with the large number of housing present in the city of Manado. The existence of new settlements in the form of housing demands religious facilities, namely places of worship. For clarity, the latest data relating to the development of detailed worship areas such as mosques and prayer rooms for Muslims, churches, chapels for Christians and Catholics, and other religious groups per district can be seen.

Table 2 Number of Places of Worship Facilities According to the District in Manado City

\begin{tabular}{|c|c|c|c|c|c|c|}
\hline \multirow[t]{2}{*}{ Sub-district } & \multirow[t]{2}{*}{ Mosque } & \multirow{2}{*}{$\begin{array}{l}\text { Prayer } \\
\text { Room }\end{array}$} & \multicolumn{2}{|c|}{ Church } & \multirow[t]{2}{*}{ Pura } & \multirow[t]{2}{*}{ Vihara } \\
\hline & & & Protestant & Catholic & & \\
\hline Malalayang & 14 & - & 74 & 2 & 1 & 1 \\
\hline Sario & 7 & 1 & 23 & - & - & 3 \\
\hline Wanea & 16 & 1 & 86 & 2 & 1 & - \\
\hline Wenang & 13 & 5 & 46 & 1 & - & 3 \\
\hline Tikala & 15 & 1 & 33 & 3 & 1 & 5 \\
\hline Mapanget & 25 & 4 & 91 & 9 & - & 1 \\
\hline Singkil & 26 & 7 & 34 & - & - & 2 \\
\hline Tuminting & 28 & 6 & 52 & 1 & - & - \\
\hline Bunaken & 22 & 3 & 62 & - & - & - \\
\hline Bunaken Islands & 1 & 1 & 25 & - & - & - \\
\hline Paal Dua & 27 & 3 & 53 & - & - & 1 \\
\hline Manado & 194 & 31 & 579 & 18 & 3 & 16 \\
\hline
\end{tabular}

Source: Manado City Ministry of Religion Data for 2019

The growth of churches and mosques was quite significant from 2010 - 2013. This increase averaged 10-15 places of worship each year, both churches and mosques. In 2010/11, the number of mosques was 150; in 2013, it reached 187 plus a prayer room with 29-likewise, the growth of church buildings, especially those of Protestant Christians. In 2010/11, the number of church buildings was 430s; in 2013, it reached 523, and this figure has not been added to Catholic church buildings in the form of churches and chapels.

In its development, several facts in the field, the regulations that are expressly stated as guidelines for the regional government's duties, have not been observed and implemented optimally by several local governments. (KBB Report) Condition of Freedom of Religion/Belief and Religious Minorities in Indonesia 2018 
Technocratically, regulations at the central level provide opportunities or even trigger regional governments to commit violations of freedom of religion/belief, especially in discriminatory policies. Regulations at the mid-level, especially at the ministerial level, are a trigger point for violations of freedom of religion/belief must be revised immediately or even completely canceled.

We must maintain tolerance and harmony amid national diversity. Without tolerance, it does not rule out problems or conflicts that can threaten the nation's unity. We will never be separated from the interactions and social processes between other people and us in everyday life. Interacting between social individuals or groups, of course, will run well if it is based on a good character too. Character means the right attitude and behavior. Good qualities will bring good and vice versa; terrible things will also produce bad. Therefore, we need to uphold noble moral values. The teachings of character demand that we always do good, righteousness, and cultivate harmonious relationships between humans and God, humans, and humans, and humans, and the environment. Tolerance is a form of social action that is moderate in terms of differences-being tolerant means that we respect and affirm democratic values that uphold freedom in diversity. Each individual has the same right to act and act as long as it does not conflict with the applicable law.

There have been many discussions about tolerance, especially in response to problems of religious diversity or plurality. Only when people behave well at every step and show tolerance towards people of the same or different religions can tolerance be achieved. This attitude will not emerge by itself if it is not based on formal and non-formal education and good human morality. Of course, there are some areas with different religions and customs that are very well tolerated, for a reason.

To set an example for our lives, this is worth studying, especially for the most educated but intolerant of people. The foundation of our country's ideological system is Pancasila. The first precept says, "the Supreme Lordship." This order instructs all Indonesian people to believe that God Almighty is the main foundation of life. Religious issues are also explained in Article 29, paragraph 2 of the Constitution, which reads: The state guarantees each resident's freedom to embrace his or her religion and worship according to that religion and belief. Then the issue of tolerance is also discussed in the Joint Regulation of the Minister of Religion and the Minister of Home Affairs concerning Guidelines for Implementing the Duties of Regional Heads / Deputy Regional Heads in Maintaining Religious Harmony, Empowering Religious Harmony Forums, and Establishing Houses of worship in chapter 1 General Provisions Article 1, in Joint Regulations this is what is meant by:

1. Religious harmony is a condition of reciprocal relations between religions based on maintaining tolerance, mutual understanding, mutual respect, respect, and equality in carrying out their religious teachings based on Pancasila and the 1945 Constitution. 
2. Maintaining religious harmony is a joint effort between religious communities and the government in terms of service, supervision, and religious communities' empowerment. Forst in Misrawi (2010) states, there are two views on tolerance, namely a concept based on national authority (permission conception) and a concept based on culture, and a willingness to build understanding and respect for others (respect conception). In this case, Forst prioritizes the second concept, that tolerance in the context of democracy must build mutual understanding and respect among the diversity of races, religions, races, and languages. Purwadarminta's "Big Indonesian Dictionary" is not much different from the second Forst concept. Tolerance is a tolerant attitude or nature, and its form is to respect and allow positions, opinions, opinions, beliefs, or other things that are different from one's position. Position. If society pays attention to and treats others emphatically in daily life, then tolerance between religious communities will be achieved. According to Walzer's view in Misrawi (2010), tolerance must be able to form possible attitudes, including 1 . Acceptance of differences 2 . It is changing the unity of diversity 3 , recognizing the rights of others 4 , respecting the existence of others 5-enthusiastic support Against differences culture and diversity created by God.

The city of Manado is surrounded by a harmonious, safe, and serene atmosphere without worry and fear, tolerance between individuals and groups of people in a family atmosphere. There are no more social conflicts, both horizontal (nuances of $S A R A$ ) and vertical (between the community and government and state apparatus (Zero Eksident). And the Creation of Order, Peace, and Protection of the Community (reduced crime rate). Through the FKUB Forum, this is an opportunity to realize religious harmony. Therefore, concrete steps need to be taken to strengthen and strengthen FKUB at the provincial and city levels. There are many ways to improve FKUB capabilities. First, strengthen the organizational structure so that all FKUB instruments can be shared and run according to their respective duties. This institution's uniqueness is that, for the first time, different religious leaders have gathered in cooperation forums throughout the country. Of course, once a person wants to become a member of FKUB, he must change his mentality, namely not only hoping that he can tell his religious group of origin, but it has been in the interest of all the group's religion in the city. Second, FKUB is not only an organization that works occasionally but also has to do full time to carry out internal and interfaith dialogue, adapt to aspirations and spread religious aspirations, socialize harmonious regulations/laws, and empower communities.

The Forum for Religious Harmony (FKUB) must prepare an annual work plan and prepare a budget to fund this activity; FKUB must regulate internal and external work procedures, formulate work mechanisms, and secretarial affairs. To find out how the Manado City FKUB carries out its role as stipulated in the Joint Regulation of the Minister of Religion and the Minister of Home Affairs Number 9 and 8 of 
2006, it is deemed necessary to conduct research, to what extent FKUB has implemented this role in Manado City.

Departing from the background and limitation of the questions above, the research questions that need to be answered are as follows: Does the implementation of the joint regulation of the Minister of Religion and the Minister of Home Affairs, especially regarding FKUB in Manado City, go as expected.

\section{B. LITERATURE REVIEW}

Etymologically, policy comes from the Greek word "Polis," which means city (city). According to Syafaruddin (2008), a policy is called a policy that deals with the idea of organizational regulation and is a formal pattern that is accepted equally by the government/institution so that it seeks to pursue its goals. Based on this opinion, it appears that policy is a mindset originating from any institution/government, which is manifested at the level of generating ideas, aiming to regulate all life in that institution through the formulation of acceptable and acceptable legislation - used by the general public for its purpose. Abidin (2006), explains "policies are government decisions that are general in nature and apply to all members of society." Meanwhile, Greston (2002) states that "public policies are made and implemented at all levels of government; therefore, the responsibilities of policymakers will be different at each level according to their authority." From the description of the situation, the decision-making process, and various considerations surrounding this condition, especially considerations related to the policy formulation stage. Anderson (2006), explains that policy is a relatively stable action deliberately designed by one participant or several participants to solve a problem or problem of mutual concern. Anderson believes that public policies formulated by government institutions and officials have a significant impact on society.

Grindle Policy Implementation (1980), states that implementation is a general process of administrative action that can be investigated at a specific program level. Van Meter and Van Horn (Wahab, 2002) suggest that policy implementation is taken individually or collectively by the government and private sector to achieve goals. Grindle (1980) adds that the implementation process starts only after objectives are set, activity plans are made, and preparation for achieving goals and preparing budget allocations. According to Lane (1987), implementation can be divided into two parts. First, realize $=\mathrm{F}$ (mean, output, result). According to this definition, execution is a function consisting of the intent and purpose, result as result and effect. Second, the realization is similar to the realization function $=F$ (strategy, formature, implementer, initiator, time). The main focus of these two functions is the policy itself, then the executor's results, and implemented within a certain period.

Policy implementation links policy objectives and their realization with the results of government activities. This is following the views of Van Meter and Van Horn (Grindle, 1980) that the task of implementation is to build networks that can achieve public policy goals through the activities of government agencies that involve various parties (policy stakeholders). 
The Policy Implementation Model developed by Van Meter and Van Horn considers policy dimensions, namely: 1 influence that policy implementation. Changes that will be generated 2. Scope of objective agreement between parties involved in the implementation process, especially those who operate the field's policies. Another thing that was put forward by Van Meter and Van Horn was how to connect policies and goals to be achieved separated by several interrelated independent variables, namely: 1. Size and Policy Objectives 2. Policy sources 3. Characteristics or agency bodies executor 4 . Communication between organizations related to implementing activities 5 . The attitude of implementers 6 . The economic, social, and political environment,

Implementation is a series of activities that aim to publish policies to the public so that these policies can produce the expected results. This series of activities include the preparation of other regulatory instruments which constitute policy interpretation. For example, many "Government Regulations," "Presidential Decrees," and "Regional Regulations" have emerged from a law. They have prepared resources to drive implementation, including facilities and infrastructure, financial resources, and responsible for implementing the policy and how to implement it, especially for the community. In principle, policy implementation is a way for a policy to achieve its goals, nothing more or less. There are two choices of steps to implement public policy, namely directly implementing it in the form of programs or through the formulation of a derivate policy or a derivative of the policy.

Public policy in the form of statutory regulations or regional regulations is a type of policy that requires explanatory public policies or generally called implementing regulations. Public policies that can be directly implemented include Presidential Decrees, Presidential Instruction, Ministerial Decrees, Regional Government Decrees, Decree of the Head of SKPD (Dwijowijoto, 2004). Daniel A. Mazmanian and Paul A. Sabatier (Wahab, 1997) explained the meaning of this implementation. He said: Knowing the actual situation after a plan is declared effective or formulated is the focus of policy implementation, namely events and activities that are forwarded through national policy guidelines. Emerged later, covering policies and management efforts that impacted or had a real impact on society.

\section{METHOD}

This research is qualitative. In collecting data using interview techniques, literature study, collecting related documents, and limited observation at the research location. Interviews were conducted with the Chairperson and several FKUB administrators, the Head of the Ministry of Religion, the head of the National Social and Political Science and Politics division and, religious and community leaders. Literature/document studies are conducted on books related to FKUB, dialogue papers, letters associated with FKUB tasks. Meanwhile, observations were made on the FKUB office in the office. In analyzing the data is done descriptively. The data collected includes a general description of the research location, the 
formation process of FKUB, the role of FKUB, supporting, and inhibiting factors. FKUB facilities and infrastructure related to budget and secretarial matters.

\section{RESULT AND DISCUSSION}

The socio-cultural life of the people of Manado City with the adhesive symbol of Torang samua basudara (all of us are brothers), this phenomenon of the daily life of the people of Manado City has been going on for hundreds of years. No matter there are differences in religion between indigenous or non-indigenous people, it can be seen in marriage, death, and even chapel construction. If every community member does not provide assistance in the form of attendance and does not contribute energy or gifts based on their existence, they will feel guilty or change their habits.

The color of community life in Manado City makes their attitude of life tolerant, united, and open to the outside world. They are easy to assimilate with outsiders (migrants) because of marriages (between races or between religions) between residents and migrants as long as it does not violate local customs or culture. Therefore, in a village with hundreds or even thousands of Christians, it is not surprising that some Muslim families lead peaceful and quiet lives and can enforce their religious laws without interference.

Optimization of FKUB Duties According to the Head of the Manado City FKUB Pdt. Renata Ticoalu, S.Th, Management of FKUB This period consisted of 17 members who represented all religions. The spirit of togetherness is the strength of FKUB management, even though there is no salary, the role of FKUB is vital.

Furthermore Pdt. Renata Ticoalu said that Pancasila values are essential to be applied as a personality in behavior; openness is needed in communication. This is important to be able to understand each other. Tolerance is openness, understanding, and respect for others. This is the spirit that strengthens FKUB administrators. Sofyan Lafasau, Secretary of the Manado City FKUB, said that the internal communication of FKUB administrators was excellent, especially in responding to problems that arise. Regardless of the time, midnight or early morning, also coordinate with each other by telephone. For example, when responding to the mosque attack in the Agape Minahasa Utara housing complex by a group of people who are directly adjacent to the city of Manado, they immediately went out to coordinate with all religious leaders to prevent it from spreading to the issue of $S A R A$. Furthermore, Sofyan Lapasau said that coordination at the board level is essential. Including communication with the government and the community can be seen in responding to various things such as a meeting between religious leaders and the local government and then serving food that they think cannot be consumed by Muslims.

Head of the Manado City Ministry of Religion Office Irwan Musa, SE, said that it is necessary to coordinate with the Manado City government to strengthen the FKUB as an effort to enhance the institution because the role of FKUB is significant as the spearhead in early detection of religious problems in society. FKUB should not 
be needed when a new emergency is necessary, like a fire extinguisher, said Irwan Musa, Pdt, also conveyed the same thing. Renata Ticoalu, Head of FKUB, we are like firefighters; we will look for new problems. The main task of FKUB is to carry out a dialogue with religious and community leaders, accommodate the aspirations of religious mass organizations and the aspirations of the community, channel the aspirations of religious organizations and the community in the form of recommendations as to materials for the Mayor's policy and disseminate the legislation and policies in the religious sector related to harmony. Religious communities and community empowerment and providing written recommendations on applications for the establishment of houses of worship. This task is still constrained by budgeting. All FKUB activities are now just following invitations, both socialization to the sub-district or other activities from the Manado City Government, and coordination with National and Political Unity and the protection of the community and the Provincial FKUB with personnel who take turns taking part. The importance of the Socialization of Manado people seems hopeful that FKUB can solve their interests. Field experiences show the impression that the community not only consults about FKUB tasks but also irrelevant matters, but they really expect FKUB assistance/support in dealing with social problems. "Good community response, people hope FKUB activities as often as possible, better persuasive," said Pdt. Renata Ticoalu. Therefore, the intensity of the socialization needs to be increased. Said Sofyan Lapasau. FKUB Secretary, Socialization must continue, because people need to be touched. Hanny Solang, Head of the National Political Unity and Community Protection Agency, Head of the Manado Kesbangpol, said that the City Government has carried out the development of subdistrict FKUB in the sub-districts by involving the City FKUB as a resource. Activities take turns in each district, with questions and answers. It is hoped that there will be openness from the participants. Thus many problems can be resolved immediately. The response can be fast. Likewise, in community socialization, FKUB is a resource for Kesbangpol activities with the budget sourced from the APBD. It's just that actions are constrained in budgeting so that the intensity of workouts is reduced. Likewise, about 35 participants in the socialization and training of FKUB in each sub-district, consisting of religious leaders, community leaders, traditional leaders, youth, attended by the local sub-district government and FKUB administrators. Of course, this is less effective and massive, according to the Head of FKUB Pdt. Renata Ticoalu, through the 2019 Manado City Regional Development and Expenditure Budget, FKUB activities, can be carried out by involving all religious leaders.

Historically, in the early period, FKUB Manado City received support from religious leaders. But financial support from the local government and the Ministry of Religion is still lacking. So this is an obstacle for FKUB to carry out its activities in participating in maintaining a peaceful and peaceful community condition. In the 2019 Fiscal year, according to Irwan Musa, the Head of the Manado City Ministry of Religion Office, FKUB received an operational budget of 50 million from the 
Ministry of Religion. This budget is used for board coordination and funding FKUB meetings.

Furthermore, Irwan Musa, the city government, needs political will for FKUB, especially by making regulations and providing funding for activities. In line with that, Pdt. Renata hopes for funding support from the City Government as in the previous period. "Hopefully, the budget constraints do not make the management apathetic," said Sofyan Lapasau, secretary of the Manado City FKUB.

FKUB policy implementation is an effort to reorganize according to an ideal concept; it is the traditional umbrella and its activities from a legal perspective. Based on experience, the Manado City Government has several weaknesses or obstacles in implementing FKUB policies. For this policy to be sustainable in the future, it is necessary to take the following strategic steps to build an alternative model of policy sources, as shown below: 1. Policy Formulation. The Government of Manado City needs to focus on the vision of development, namely "The creation of living conditions for people throughout the city of Manado, which is covered in a harmonious, safe and serene atmosphere without worry and fear, tolerance between individuals and groups in a family atmosphere" can accelerate the influence of other sectors. It is hoped that play a role in capacity building, "Smart" and in the joints of life through the Forum for Religious Harmony. This concept is ideal and noble; however, there are still obstacles in policy implementation in terms of technical and conceptual coordination. Therefore, it is necessary to use regulation as an umbrella for regulatory law and as the basis for city government budgets.

Therefore, it needs to be formulated so that the implementation model is specific and precise. This policy formulation is the same as Syafaruddin (2008), that the policy is called an organizational regulation policy, and is a formal model that is also accepted by the government/institution to strive to achieve its goals. The procedures and legal hierarchy of regulations with FKUB ministers formulated by the Manado City Government are supported by Anderson's (2006) theory, divided into four types of public policies: substantive and procedural policies of a government agency and its strengths and procedures. Then, Anderson (2006), explained again that policy is a relatively stable action deliberately designed by actors or many actors to solve problems or issues of mutual concern. Anderson believes that public policies formulated by government agencies and officials have a significant impact on society. Besides, after developing policies that meet the implementation level, the budget is used as a funding source. FKUB policy implementation is closely related to budget and planning. The concept of a budget focuses on the political aspect. Does this policy plan aim at realizing community harmony? The formulation work started with the Mayor and the DPRD.

The implementation of FKUB policies formulated by the Manado City Government is indeed easy to understand abstractional. It seems easy to implement; in practice, its performance is not as easy as imagined. Strategy implementation always requires the availability of resources or strategic resources as a necessary condition to ensure smooth implementation. There are still several findings that 
become weak points as reconstruction data. FKUB policy implementation and development conditions are related to the following:

So that at the level of policy implementation, it is easier to coordinate, the city government of Manado has formed an FKUB whose organizational structure is based on a Mayor's Decree, whose formulation is quite regular in terms of duties. This structured accountability system is the same as Ripley and Franklin's theory (in Widodo, 2001), the latter is based on three aspects, namely: (1) The degree of bureaucratic compliance with the bureaucracy mentioned above or the bureaucracy required by the law Degree of ism; (2) smooth daily affairs. No problem; (3) The targeted implementation and impact of all existing plans (benefits). At the same time, according to Goggin et al. (in Widodo, 2001), the policy implementation process is based on the following variables to measure the success of transferring its performance from a higher institution to a lower one: (1) Encouragement and coercion at the federal level, (2) State Center/Capacity (3) Encouragement and pressure at the central and regional levels. The variables of encouragement and coercion of the central government depend on legitimacy and credibility; namely, the more effective central government policies are in the regions' eyes, the higher their credibility, and vice versa. According to the opinion of the experts above, the PKK, which is formed by the Manado City Government, must be able to carry out its duties properly and take full responsibility.

Therefore, the success or failure of a policy depends very much on FKUB administrators' role as the management team to forward policy information formulated by the central government to the city. This structured accountability system is based on the compliance of the bureaucracy with the upper-level bureaucracy or the predetermined level of bureaucracy, smooth progress of daily affairs, and problem-solving; Therefore, the success or failure of a policy depends very much on the role of FKUB administrators as the management team to forward policy information formulated by the central government to the city. This structured accountability system is based on the bureaucracy's compliance with the upper-level bureaucracy or the predetermined bureaucracy, daily affairs' smooth progress, and problem-solving.

\section{E. CONCLUSION}

The Forum for Religious Harmony in Manado City is the main spearhead for realizing religious harmony as the Government of Manado City Vision 2016-2021. For this reason, concrete steps are needed to empower and strengthen the presence of FKUB both in cities and districts. They are strengthening organizational institutions by enabling all FKUB devices to function according to their respective division of tasks. The FKUB of Manado City must function properly even though this city has never experienced a significant conflict over religion, with the gathering of religious leaders in this collaboration organization. And religious leaders who are willing to become members and administrators of FKUB are those with a national mindset, that is, they are not only expected to voice a group of religious people from 
which they originate, but they have become representatives of the interests of the entire ummah. The FKUB of Manado City should not be just a forum that works only incidentally or only attends activities based on the invitation but works full-time to carry out internal and inter-religious dialogue, accommodate aspirations and channel the aspirations of religious communities, socialize laws and regulations on harmony, and conduct community empowerment. For this reason, FKUB should prepare an annual work program and compile a budget to finance activities. As well as collecting both internal and external work procedures, formulating work mechanisms, and a representative secretariat.

To the FKUB board, they should maintain a national attitude in carrying out their duties above the diversity of Manado society and the limited facilities in carrying out the roles and functions of the FKUB. To the City Government of Manado, the Ministry of Religion of the City of Manado and the DPRD of the City of Manado should specifically invite the FKUB Management to coordinate in evaluating the program and budgeting. Due to the implementation of the role of the Manado City FKUB, it is based on the Joint Regulation of the Minister of Religion and the Minister of Home Affairs Number 9 and Number 8 of 2006, concerning Guidelines for Implementing the Duties of Regional Heads/Deputy Regional Heads in Maintaining Religious Harmony, Empowering Religious Harmony Forums, and Building Houses Worship. Higher education institutions in Manado's city should carry out similar studies and need to be carried out as often as possible, the results of which become input for development planning for the City of Manado and scientific development and especially social sciences.

\section{REFERENCES}

1. Abidin, S. Z. (2006). Kebijakan Publik. Suara Bebas.

2. Wahab, A. S. (2002). Analisis Kebijaksaan, dari Formulasi ke Implementasi Kebijaksanaan Negara. Jakarta: Bumi Aksara.

3. Anderson, J. E. (2006). Public Policy Making: An Introduction. Boston: Houghton Mifflin Company.

4. Dye, R. T. (2005). Understanding Public Policy, by Person Education. Inc, Upper Saddle River, New Jersey, USA.

5. Grindle, M. S. (1980) Politics and Policy Implementation in the Third World. Princeton. New Jersey: Princeton University Press.

6. Joint Regulation of the Minister of Religion and the Minister of Home Affairs No. 9 and 8 of 2006.

7. Lane, J. E. (1987). Implementation, accountability, and trust. European journal of political research, 15(5), 527-546.

8. Misrawi, Z. (2010). Pandangan Muslim Moderat: Toleransi, Terorisme, dan Oase Perdamaian. Jakarta: Kompas.

9. Moleong, L. J. (2000). Metodologi Penelitian Kualitatif. Bandung: Remaja Rosdakarya. 
10. Syafaruddin, S. (2008). Efektivitas Kebijakan Pendidikan: Konsep, Strategi dan Aplikasi Kebijakan Menuju Organisasi Sekolah Efektif. Jakarta: Rineka Cipta.

11. Joint Regulations of the Minister of Religion and the Minister of Home Affairs No. 9 and 8 of 2006, Regarding Guidelines for Implementing the Duties of Regional Heads / Deputy Regional Heads in Maintaining Religious Harmony, Empowering Religious Harmony Forums and Establishing houses of worship.

12. Manado City Medium Term Development Plan 2016-2021, Bapelitbang Manado.

13. Van Meter, D. \& Van Horn, C. E. (2004). Policy Implementation. Jakarta. Rineka Cipta.

14. Widodo, J. (2001). Good governance: telaah dari dimensi akuntabilitas dan kontrol birokrasi pada era desentralisasi dan otonomi daerah. Insan Cendekia.

15. Zuraida, A. (2009). Interaksi Sosial Transmigrasi Bali dengan Suku Lain di Desa Kolam Kanan Kec arambai. UNLAM Banjarmasin. 